\title{
School-Based Practices for Entrepreneurship Skills Acquisition in Secondary Schools in Delta State of Nigeria
}

\author{
Godwin Onnoh Onajite*, Matthew Adebayo Aina \\ Department of Vocational and Technical Education, Faculty of Education, Ekiti State University, Ado-Ekiti, Nigeria
}

Email address:

onajitego@gmail.com (G. O. Onajite)

${ }^{*}$ Corresponding author

\section{To cite this article:}

Godwin Onnoh Onajite, Matthew Adebayo Aina. School-Based Practices for Entrepreneurship Skills Acquisition in Secondary Schools in Delta State of Nigeria. International Journal of Vocational Education and Training Research. Vol. 3, No. 5, 2017, pp. 40-50.

doi: $10.11648 / j . i j v e t r .20170305 .11$

Received: April 21, 2017; Accepted: May 5, 2017; Published: November 23, 2017

\begin{abstract}
This study determined school-based practices essential for entrepreneurship skills acquisition in secondary schools in Delta State. Five research questions were raised to guide the study. Descriptive survey research design was used in conducting the study. Population of the study comprised 448 principals and 3258 entrepreneurship subject teachers from 448 public secondary schools in Delta State. Purposive sampling technique was used to select a sample size of 224 principals and 652 entrepreneurship subject teachers from 224 public secondary schools in Delta State. A questionnaire titled: School-Based Practices for Entrepreneurship Skills Acquisition Questionnaire (SBPESAQ), which contained 56 items and designed on a 4 point scale was used to collect data for this study. The instrument was validated by two experts from the Department of Business Education and Department of Educational Foundations both of Nnamdi Azikiwe University, Awka. Reliability of the instrument was determined through a pilot-test conducted by the researcher on the instrument by selecting five principals and five business studies teachers from five public secondary schools in Anambra State. The result was found to have a reliability coefficient of 0.73 using the Cronbach Alpha Coefficient Measurement which indicated that the instrument was reliable to collect the necessary data for the study. Data were equally analyzed using mean score at 2.50 rating, frequencies and simple percentages. Consequently, from the findings of the study, it was discovered that there was need for introducing school-based practices in the secondary schools in Delta State; both principals and entrepreneurship subject teachers were highly aware and knowledgeable to a high extent about the types of school-based practices for entrepreneurship skills acquisition in secondary schools in Delta State; and a large percentage of principals and entrepreneurship subject teachers accepted the incorporation of school-based practices as part of their academic programme for entrepreneurship skills acquisition in secondary schools in Delta State. The study recommended among others that: State Government should provide adequate funds that will promote school-based practices in the secondary education system. Adequate resources should be utilized as a way of enhancing school-based practices in the secondary education system. Non Governmental agencies and other private institutions should support school-based practices by rendering to secondary schools some financial assistance, support resources and assisting schools to collaborate with enterprises that will boost school-based practices for entrepreneurship skills acquisition in the secondary education system.
\end{abstract}

Keywords: School-Based Practices, Entrepreneurship, Skills, Secondary School, Delta State

\section{Introduction}

Education is a veritable tool that unlocks students' potentials for creativity and national development. Education serves as an instrument which enables individuals solve their problems and to meet up with their expectations. It enables individuals to meet up with fundamental changes in the society. Regardless of benefits of education, for any nation or society to meet up with her developmental goals, means that their education systems must be functional, involving schoolbased practices aimed at achieving the developmental goals. Functional education (given entrepreneurship skills acquisition) however equips individuals with rightly competences and skills that will enable them participate 
actively in the socio-economic development of the society. Essentially, entrepreneurship education avails students' with the functional skills that will enable them handle their businesses in the future for maximum profit. According to Ezeani [1], entrepreneurship education creates the willingness and ability in a person to seek out investment opportunities in the society and be able to establish and run an enterprise successfully based on the identified opportunities. It refers to programmes that promote and provide skill training for business creation and development. Entrepreneurship education is the type of education which has the ability to impact on the growth and development of an enterprise through training

Entrepreneurship is the aspect of education which equips an individual and creates in the person the mindset to undertake the risk of venturing into something new by applying the knowledge and skills acquired in school [2]. In the light of the above definitions, this means that entrepreneurship education helps to provide business studies and all other education students with the knowledge, skills and innovation to encourage entrepreneurship in variety settings. However, it is considered that such skills acquisition through entrepreneurship education will build up the confidence in the students to engage in entrepreneurship venture after graduation [3]. This calls for entrepreneurship education that will equip secondary school students upon graduation to be fitted in the dynamic society. School-based practices as defined by the National Research Center for Career and Technical Education [4] is any simulated or actual business and industrial activity, experience(s) or training (s)conducted by a school for skill acquisition. It replicates a specific business or industry, and is a learning experience that provides direct links between students, their curriculum and the world of work. The programmes must be oriented and run by students. Teachers serve as advisors, but not chief executive officers. Some school-based practices operate like regular small businesses, letting students apply the academic and vocational content they have learned in school. A School-based practice can also give students real practice in entrepreneurship, accounting, budgeting, cash flow management, marketing, inventory control, and business/industry/technical skills. Students exposed to different school-based practices experience generic work skills in problem solving, communication, interpersonal relations, and learning how to learn in the context of work. The researcher in this present study defines school-based practices as those practices engaged by schools' officials which includes the use of practical's, internship programmes, external resource persons, vacations training, field trips and excursions, apprenticeship, establishment of entrepreneurship centre, among others, for students' entrepreneurship skills acquisition. These school-based practices is essential for students academic development and needed owing to the need to: expose students to practical aspects of the teaching and learning that takes place in the classroom; show students the connection between the work-based learning and specific coursework; enable students to have reflection on their learning; and allow time in the school schedule for students to participate in work-based learning [4]. No doubt, the current economic challenges and situation facing many countries across the globe (including Nigeria), makes the notion of engendering greater entrepreneurial activity to become a prominent goal for many national governments. Concerns about matters such as the availability of skilled labour, lack of competition, favourable government policy and economic climate, need to achieve the educational policy objectives on entrepreneurship proficiency, supportive legislation and easy access to markets, individuals ability to grow their business as identified [5]; all contributed towards the need to strengthen school-based practices for entrepreneurship skills acquisition. The relevance of schoolbased entrepreneurship practices to economic development which cannot be overemphasized has been highlighted by many researchers like Cooney [5].

School-based practices prepares youths to be responsible and entering individuals, who become entrepreneurs or entrepreneurial thinkers by exposing them in real life learning experiences where they will be required to think, take risks, manage circumstances and incidentally learn from the outcome [6]. Its benefits as further highlighted by Cooney include; developing entrepreneurial capacities and mindsets' that benefit economies by fostering creativity, innovation and self-employment. From the foregoing, it is now wellrecognized that education and training opportunities play a key role in cultivating future entrepreneurs and in developing the abilities, creativity and skills of existing entrepreneurs to grow their business to greater levels of success. In this respect, skills as defined by [7] refers to proficiency in performance and may be enhanced by practice and training. They are multidimensional constructs which comprise the cognitive-knowledge and what is learnt; the affectiveemotional expression and what is experienced; the behavioraction at strategic, tactical and personal levels; and the context-sectoral, occupational, job and task levels. Entrepreneurship skills acquisition is associated with competence in the process of opportunity identification (and/or creation), the ability to capitalize on identified opportunities and a range of skills associated with developing and implementing business plans to enable such opportunities to be realized [7]. Skills acquisition as defined by [1] is the art of possessing the ability to power, authority, or competency to do the task required of an individual on the job. Johnson, Snowden, Mukhuty, Fletcher and Williams [7] further identifying skills acquired through entrepreneurship envisaged the following: identifying customer needs, technical opportunities and market opportunities, as summarized by Hayton; creation of new opportunities, as pointed out by Alvarez and Barney; recognizing social/market needs; and successful entrepreneurs may find (or create) an opportunity and then develop skills to capitalize on the opportunity. Additionally, the National Research Center for Career and Technical Education [4] pointed out some of the school-based practices necessary for entrepreneurship skills acquisition to include: internship/co- 
operative education and apprenticeship training. Describing these practices, NRCCTE defines internships as sustained work-based learning experiences designed to enrich and expand classroom learning, showing students how their learning is applied in the world outside of school, and offering access to tools, equipment, facilities and expertise that generally are not available at school. Apprenticeship is a method of training that emphasizes learning by doing. Apprentices are taught by experienced workers and supervisors at the job site and practice their skills in real work assignments. These two programmes have all the features needed to prepare students for occupations that require extended study to attain competence. The procedures learned and equipment used are in the workplace, so there is no need to transfer what is learned in the classroom to what is done on the job. The work itself provides multiple opportunities to practice the skills being learned.

Supporting the above, [8] and [9] identified some schoolbased strategies for promoting entrepreneurship in business education curriculum to include; business teacher entrepreneur counselor, on-the-job training, school workshops and seminars for acquisition of entrepreneurship education skills. Despite all the above discussions, schoolbased practices can be successful only when the principals and business education teachers are aware and ready to accept such practices in the secondary school system. The principal is the chief executive in the school who directs other staff to carry out their task diligently. According to Chike-Okoli [10], the principal as the school manager, change facilitator, supervisor and instructional leader, should provide teachers with sound instructional leadership and practices as this is the only way any school instructional programme can be improved in schools. Similarly, the principals in the secondary schools in Delta State must be ready to accept and adopt school-based practices and likewise inculcate the same values to the entrepreneurshiptaught subject teachers who interact with students in the classroom. The teachers on the other hand, who are also implementers of education policies in the school, must be ready to accept and adopt the school-based practices for effective instructional delivery in the teaching and learning of entrepreneurship education for skills acquisition. In the words of Queensland Government;

Effective teachers use an array of teaching strategies because there is no single, universal approach that suits all situations. Different strategies used in different combinations with different groupings of students will improve learning outcomes. Some strategies are better suited to teaching certain skills and fields of knowledge than are others. Some strategies are better suited to certain student backgrounds, learning styles and abilities [11, p8].

Barr and Miller also cited in [11] made it clear that best practices could be marred if the physical environment that promotes learning is not put in place and sustained. However, school-based practices can succeed in the secondary schools in Delta State only if there is rapport well established rapport with and within groups, example: principals and teachers
[11]. In Delta State, entrepreneurship education which inculcates in the students rightful skills and competences that enable them participate fully in socio-economic activities are also taught under subjects like business studies, commerce, accounting, economics, computer, food and nutrition, home economics, basic technology, cultural creative arts, among others, but in reality there are no school-based training for students [12]. Students are only exposed to too much theory with little considerations for practical exercises. At the end of the day, students graduate without having the requisite entrepreneurial skills that will enable them function well in the society. In contrast, during the colonial administration in Nigerian education, students were exposed to practical training but such practices no longer exist in the school systems. Emphasis is placed more on theory with little or no attention focused on practical. This situation which has implication on the quality of learning provided in the secondary school system call for readdressing by all education stakeholders.

\subsection{Statement of the Problem}

Promoting the quality of teaching and learning in secondary schools in Delta State is highly dependent on effective utilization of school-based practices. No doubt, developing and promoting entrepreneurship education through school-practices for students' skills acquisition and functionality has been one of the key policy objectives for the Nigerian government and other education stakeholders for some years. There has been a growing awareness of the potential of young people to launch and develop their own commercial or social ventures thereby becoming innovators in the areas in which they live and work. School-based entrepreneurship practices for skill acquisition are essential not only to shape the mind-sets of young people but also to provide the skills, knowledge and attitudes that are central to developing an entrepreneurial culture. Education according to Nneji in [1] is supposed to prepare an individual for a career in life. Unfortunately, most Nigerian children go into various stages of education, right from the primary to tertiary institutions without any preparation for whatever career stages they aim at. Today, there are many graduates without jobs while there are many jobs without people. When secondary school leavers acquire sellable skills, they become useful to the society as trained craftsmen with financial and psychological security and their employer receives productive work from them.

The society at large receives continuous supply of skilled labour and quality goods. Evidently, possession of skills is important in preventing youths from becoming social misfits; because, these skilled persons become gainfully employed through vocational training and acquisition of skills. The economy needs skilled people to produce the goods and services demanded by the society. The future of the present Nigerian secondary school leavers in general and that of Delta State in particular should be a great concern to all who think of the development of the country. The Federal Republic of Nigeria stated that secondary education is the 
form of education children receive after primary education and before tertiary levels [12]. The National Policy on Education provided for vocational emphasis in the junior and senior secondary schools to make it possible for recipients who cannot continue their education to the next level to find a useful job. It is important to be mindful of the general level of different skills in an economy so as to achieve a balanced development and high productivity in skill acquisition. To achieve skill acquisition in the secondary schools in Delta State, there is need to introduce school-based practices as a way of monitoring all areas of teaching and learning inculcating entrepreneurship in students in order to ensure that effective linkages exist between attempts to develop theory and practical skills [8]. This could be made to enrich academic curriculum and as such utilize the great potential in academic institutions. It would also create an venue for interaction among the various sectors in economy with the secondary schools in Delta State such as the artisans, manufacturers, academicians, service providers, government and industries in a way to enhance rapid skill acquisition and technological development in the country. In a bid to fill the existing gap in secondary education in Delta State, such has warranted this study to determine school-based practices for entrepreneurship skills acquisition in secondary schools.

\subsection{Purpose of the Study}

This study aimed at examining school-based practices for entrepreneurship skills acquisition in secondary schools in Delta State. Specifically, the study determined:

1. The existing situations which call for the introduction of school-based practices for entrepreneurship skills acquisition in secondary schools in Delta State.

2. The benefits of school-based practices for students' entrepreneurship skills acquisition in secondary schools in Delta State.

3. The level of awareness of both principals and entrepreneurship-taught subject teachers of the types of school-based practices requisite for entrepreneurship skills acquisition in secondary schools in Delta State.

4. Principals acceptability of the various school-based practices for entrepreneurship skills acquisition in secondary schools in Delta State.

5. Entrepreneurship-taught subject teachers' acceptability of the various school-based practices for entrepreneurship skills acquisition in secondary schools in Delta State.

\subsection{Research Questions}

The following research questions guided the study:

1. What are the existing situations which call for the introduction of school-based practices for entrepreneurship skills acquisition in secondary schools in Delta State?

2. What are the benefits of school-based practices on students' entrepreneurship skills acquisition in secondary schools in Delta State?

3. What is the level of awareness of both principals and entrepreneurship-taught subject teachers of the types of school-based practices requisite for entrepreneurship skills acquisition in secondary schools in Delta State?

4. What percentage of principals' accepts school-based practices for entrepreneurship skills acquisition in secondary schools in Delta State?

5. What percentage of entrepreneurship-taught subject teachers' accepts of school-based practices for entrepreneurship skills acquisition in secondary schools in Delta State?

\section{Method}

\subsection{Design}

The descriptive survey design was used for conducting the study. The design sought to collect data on the opinions of the participants (principals and entrepreneurship-taught subject teachers) with a view to investigate school-based practices for entrepreneurship skills acquisition in secondary schools in Delta State.

\subsection{Population}

The study population comprised all the 448 principals of public secondary schools and 3258 entrepreneurship-taught subject teachers in Delta State whose population comprised a total of 3706. Justification for choosing principals and entrepreneurship-taught subject teachers is because both principals and teachers implement education policy at the classroom level and their dispositions in the present study will give proper account of the situation in Delta State. The sample size for the study involves 224 principals and 652 entrepreneurship-taught subject teachers teaching in the secondary schools in Delta State.

The purposive sampling technique was used to select the samples for the study. The sample represents $50 \%$ of the principals including their secondary schools and $20 \%$ of the entrepreneurship-taught subject teachers selected from the entire population of the study.

\subsection{Instrumentation}

A self-developed questionnaire titled: School-Based Practices for Entrepreneurship Skills Acquisition Questionnaire (SBPESAQ) designed by the researcher was used as the main instrument for data collection. The instrument contained 56 items and designed on 4-point scale of: (a) Strongly Agree - SA (4), Agree- A (3), Disagree - D (2), and Strongly Disagree - SD (1), for answering research questions 1 and 2. Item responses such as: Very High Extent - VHE (4), High Extent - HE (3), Low Extent- LE (2) and Very Low Extent - VLE (1) was used for answering only research question 3. While items responses such as: Strongly Acceptable - SA (4), Acceptable - A (3), Not Acceptable NA (2) and Strongly Not Acceptable - SNA (1) was used for answering research questions 4 and 5 . The research instrument tagged SBPESAQ was organized into five (5) sections. Section A contained 12 items eliciting information relating to the existing situations which calls for the 
introduction of school-based practices for entrepreneurship skills acquisition in secondary schools in Delta State. Section B contained 8 items eliciting information relating to the benefits of school-based practices for students' entrepreneurship skills acquisition in secondary schools in Delta State. Section C contained 12 items eliciting information relating to the level of awareness of both principals and entrepreneurship-taught subject teachers of the types of school-based practices requisite for entrepreneurship skills acquisition in secondary schools in Delta State. Section D contained 12 items eliciting information relating to principals acceptability of the various school-based practices for entrepreneurship skills acquisition in secondary schools in Delta State. Section E contained 12 items eliciting information relating to entrepreneurship-taught subject teachers' acceptability of the various school-based practices for entrepreneurship skills acquisition in secondary schools in Delta State. The items required an "Agreement" or "Disagreement" answer.

The research instrument was validated by two experts from the Department of Business Education and Department of Educational Foundations via Measurement and Evaluation Unit, Nnamdi Azikiwe University, Awka, to establish the face and content validity in line with the purpose of the study.
The corrections and modifications made by the experts on the instrument to ensure its validity were incorporated in the final correction of the instrument.

Reliability of the instrument was determined through a pilottest conducted by the researcher on the instrument, selecting five principals and five entrepreneurship-taught subject teachers from five public secondary schools in Anambra State. The result was found to have a reliability coefficient of 0.73 using the Cronbach alpha coefficient measurement which indicated that the instrument was trustworthy to collect the necessary data for the study. This further affirmed that the instrument was reliable for the study. The research instrument was finally administered and collected by the researcher with the help of two research assistants who received briefings on how to administer the instrument on the participants. Method of data collection also involved a personal, hand delivery and face to face contact with all the respondents. An on the spot method was employed in order to collect the research instrument where applicable, if not such participant was given extra one day to fill the instrument. Data were analyzed using mean at 2.50 rating, frequencies and simple percentages. Any mean that rated above the benchmark of 2.50 was regarded as agree while mean rated below the benchmark (2.50) was regarded as disagree.

\section{Results}

Table 1. Mean Scores and Standard Deviation of Principals and Entrepreneurship-Taught Subject Teachers on the Existing Situations which calls for the Introduction of School-Based Practices for Entrepreneurship Skills Acquisition in Secondary Schools in Delta State N=876.

\begin{tabular}{|c|c|c|c|c|c|c|c|c|c|c|}
\hline \multicolumn{11}{|c|}{ Items } \\
\hline $\mathbf{S} / \mathbf{N}$ & $\begin{array}{l}\text { Please indicate your agreement on the existing situations which calls } \\
\text { for the introduction of school-based practices for entrepreneurship } \\
\text { skills acquisition in your school }\end{array}$ & SA & $\mathbf{A}$ & D & SD & \multicolumn{2}{|c|}{ RESPODENTS } & $\mathbf{X}$ & STD & DECISION \\
\hline \multirow{2}{*}{1} & \multirow{2}{*}{$\begin{array}{l}\text { Teaching methodology in the school which is basically theoretical needs to } \\
\text { be improved with practical knowledge and skills. }\end{array}$} & 68 & 88 & 49 & 19 & Principals & 224 & 2.92 & 0.92 & Agree \\
\hline & & 272 & 241 & 99 & 40 & Teachers & 652 & 3.14 & 0.89 & Agree \\
\hline \multirow{2}{*}{2} & \multirow{2}{*}{$\begin{array}{l}\text { Students are not been exposed to out-door classroom practices in different } \\
\text { subject areas for skill acquisition. }\end{array}$} & 81 & 68 & 43 & 32 & Principals & 224 & 2.88 & 1.05 & Agree \\
\hline & & 280 & 237 & 103 & 32 & Teachers & 652 & 3.17 & 0.87 & Agree \\
\hline 3 & $\begin{array}{l}\text { The entrepreneurial culture which are not inculcated into the students to } \\
\text { enable them develop positive attitude to work. }\end{array}$ & 299 & 247 & 43 & 63 & Teachers & 652 & 3.20 & 0.93 & Agree \\
\hline \multirow{2}{*}{4} & \multirow{2}{*}{ Poor students' preparation for future career in the world of work. } & 79 & 77 & 38 & 30 & Principals & 224 & 2.92 & 1.03 & Agree \\
\hline & & 259 & 244 & 93 & 56 & Teachers & 652 & 3.08 & 0.94 & Agree \\
\hline \multirow{2}{*}{5} & \multirow{2}{*}{$\begin{array}{l}\text { Unemployment situations in the country which calls for entrepreneurship } \\
\text { skills acquisition. }\end{array}$} & 69 & 66 & 40 & 49 & Principals & 224 & 2.69 & 1.13 & Agree \\
\hline & & 247 & 251 & 80 & 74 & Teachers & 652 & 3.03 & 0.98 & Agree \\
\hline \multirow{2}{*}{6} & \multirow{2}{*}{$\begin{array}{l}\text { Improved partnership with external business enterprises which is not found } \\
\text { in the secondary school system. }\end{array}$} & 60 & 65 & 48 & 55 & Principals & 224 & 2.57 & 1.12 & Agree \\
\hline & & 243 & 264 & 88 & 57 & Teachers & 652 & 3.06 & 0.92 & Agree \\
\hline 7 & $\begin{array}{l}\text { Difficulty in meeting up with instructional objectives of certain subjects that } \\
\text { needs practical exercises. }\end{array}$ & 233 & 243 & 99 & 77 & Teachers & 652 & 2.97 & 0.99 & Agree \\
\hline \multirow{2}{*}{8} & \multirow{2}{*}{$\begin{array}{l}\text { Students' poor exposure and knowledge about different school-based } \\
\text { practices that will improve their learning. }\end{array}$} & 87 & 69 & 28 & 40 & Principals & 224 & 2.91 & 1.10 & Agree \\
\hline & & 277 & 304 & 38 & 33 & Teachers & 652 & 3.27 & 0.78 & Agree \\
\hline \multirow{2}{*}{9} & \multirow{2}{*}{$\begin{array}{l}\text { Failure to create a functional education system and supportive classroom } \\
\text { environment that will meet up with the present day needs and demands of } \\
\text { the Nigerian society and economy. }\end{array}$} & 85 & 58 & 41 & 40 & Principals & 224 & 2.84 & 1.12 & Agree \\
\hline & & 224 & 311 & 64 & 53 & Teachers & 652 & 3.08 & 0.87 & Agree \\
\hline \multirow{2}{*}{10} & Failure in providing students with training that will enable them to become & 94 & 59 & 35 & 36 & Principals & 224 & 2.94 & 1.10 & Agree \\
\hline & creative and innovative. & 286 & 259 & 58 & 49 & Teachers & 652 & 3.20 & 0.89 & Agree \\
\hline & There is need to actualize the educational and curriculum objectives & 88 & 63 & 34 & 39 & Principals & 224 & 2.89 & 1.11 & Agree \\
\hline 11 & through school-based practices. & 300 & 251 & 56 & 45 & Teachers & 652 & 3.24 & 0.88 & Agree \\
\hline 12 & The secondary school system fails to effectively expose students to real life & 86 & 69 & 41 & 28 & Principals & 224 & 2.95 & 1.03 & Agree \\
\hline 12 & experiences that will make them become self-reliant. & 294 & 288 & 36 & 34 & Teachers & 652 & 3.29 & 0.79 & Agree \\
\hline & & & & & & Principals & 224 & 2.85 & 1.08 & Agree \\
\hline Uver & all Mean and Standard Deviation & & & & & Teachers & 652 & 3.15 & 0.90 & Agree \\
\hline
\end{tabular}


Results from Table 1 showed that both respondents' responses (principals and teachers) from items from $1-12$ rated above the accepted mean score of 2.50 indicating agreements with all the statements in the items. None of the items rated below the mean score. The grand mean of the principals and teachers were 2.85 and 3.15 with standard deviation of 1.08 and 0.90 , respectively, indicating positive reactions from both parties concerning the existing situations which calls for the introduction of schoolbased practices for entrepreneurship skills acquisition in secondary schools in Delta State.

Table 2. Mean Scores and Standard Deviation of Principals and Entrepreneurship-Taught Subject Teachers on the Benefits of School-Based Practices for Students' Entrepreneurship Skills Acquisition in Secondary Schools in Delta State N $=876$.

\begin{tabular}{|c|c|c|c|c|c|c|c|c|c|c|}
\hline \multicolumn{11}{|c|}{ Items } \\
\hline \multirow{3}{*}{$\frac{\mathbf{S} / \mathbf{N}}{13}$} & \multirow{3}{*}{$\begin{array}{l}\text { Please indicate your agreement on the benefits derived from } \\
\text { school-based practices for students' entrepreneurship skills } \\
\text { acquisition in your school } \\
\text { Prepares students' mindset to undertake the risk and challenges of } \\
\text { venturing into new business opportunities. }\end{array}$} & \multirow{3}{*}{$\begin{array}{c}\text { SA } \\
108 \\
347\end{array}$} & \multirow{2}{*}{$\begin{array}{l}\mathbf{A} \\
50\end{array}$} & \multirow{2}{*}{37} & \multirow{2}{*}{$\begin{array}{l}\text { SD } \\
29\end{array}$} & \multicolumn{2}{|c|}{ RESPODENTS } & \multirow{2}{*}{$\begin{array}{l}\mathbf{X} \\
3.06\end{array}$} & \multirow{2}{*}{$\begin{array}{c}\text { STD } \\
1.08\end{array}$} & \multirow{2}{*}{$\begin{array}{l}\text { DECISION } \\
\text { Agree }\end{array}$} \\
\hline & & & & & & Principals & 224 & & & \\
\hline & & & 259 & 17 & 29 & Teachers & 652 & 3.42 & 0.75 & Agree \\
\hline \multirow{2}{*}{14} & Improves students' competences which will make them become & 74 & 115 & 23 & 12 & Principals & 224 & 3.12 & 0.80 & Agree \\
\hline & creative and innovative in various business areas. & 287 & 274 & 44 & 47 & Teachers & 652 & 3.23 & 0.86 & Agree \\
\hline \multirow{2}{*}{15} & & 22 & 20 & 92 & 90 & Principals & 224 & 1.88 & 0.93 & Disagree \\
\hline & Teaches abstract things that makes students lazy in future. & 30 & 25 & 253 & 344 & Teachers & 652 & 1.60 & 0.77 & Disagree \\
\hline \multirow{2}{*}{16} & Provides practical training for students' to acquire competences that & 89 & 66 & 41 & 28 & Principals & 224 & 2.96 & 1.04 & Agree \\
\hline & $\begin{array}{l}\text { will make them selt-reliant and productive individuals in the world of } \\
\text { work. }\end{array}$ & 327 & 258 & 53 & 14 & Teachers & 652 & 3.38 & 0.73 & Agree \\
\hline \multirow{2}{*}{17} & Equips students with business, vocational, technical and & 78 & 103 & 24 & 19 & Principals & 224 & 3.07 & 0.89 & Agree \\
\hline & $\begin{array}{l}\text { communication skills that will enable them grow and improve their } \\
\text { business in future. }\end{array}$ & 288 & 275 & 55 & 34 & Teachers & 652 & 3.25 & 0.82 & Agree \\
\hline \multirow{2}{*}{18} & Creates emnloyment onnortunities for students in different careers & 92 & 77 & 21 & 34 & Principals & 224 & 3.01 & 1.05 & Agree \\
\hline & & 301 & 269 & 37 & 45 & Teachers & 652 & 3.27 & 0.85 & Agree \\
\hline \multirow{2}{*}{19} & Enables students become successful entrepreneurs in their various & 88 & 73 & 36 & 27 & Principals & 224 & 2.99 & 1.02 & Agree \\
\hline & vocations and businesses. & 270 & 299 & 42 & 41 & Teachers & 652 & 3.22 & 0.82 & Agree \\
\hline \multirow{2}{*}{20} & Improves the quality of learning in different subject areas in the school & 85 & 70 & 32 & 37 & Principals & 224 & 2.91 & 1.08 & Agree \\
\hline & which helps to draw students' attention and focus in a career. & 284 & 311 & 22 & 35 & Teachers & 652 & 3.29 & 0.77 & Agree \\
\hline \multirow{2}{*}{\multicolumn{2}{|c|}{ Overall Mean and Standard Deviation }} & & & & & Principals & 224 & 2.88 & 1.06 & Agree \\
\hline & & & & & & Teachers & 652 & 3.08 & 0.98 & Agree \\
\hline
\end{tabular}

Results from Table 2 showed that both respondents' responses (principals and teachers) from items 13 to 15 and 16 to 20 rated above the accepted mean score of 2.50 indicating agreements with all the statements in the items. Only item 15 of both the principals and teachers responses rated below 2.50, showing disagreement with the statement.
The grand mean of the principals and teachers were 2.88 and 3.08 with standard deviation of 1.06 and 0.98 , respectively, indicating positive reactions from both parties concerning the benefits of school-based practices for students' entrepreneurship skills acquisition in secondary schools in Delta State.

Table 3. Mean Scores and Standard Deviation of Principals and Entrepreneurship-Taught Subject Teachers on their Level of Awareness of the Types of SchoolBased Practices requisite for Entrepreneurship Skills Acquisition in Secondary Schools in Delta State N=876.

\begin{tabular}{|c|c|c|c|c|c|c|c|c|c|c|}
\hline \multicolumn{11}{|c|}{ ITEMS } \\
\hline \multirow{3}{*}{$\begin{array}{l}\mathbf{S} / \mathbf{N} \\
21\end{array}$} & \multirow{3}{*}{$\begin{array}{l}\text { Please indicate your level of awareness of the various types } \\
\text { of school-based practices requisite for entrepreneurship } \\
\text { skills acquisition in your school } \\
\text { Learning through transaction with local and external agents. }\end{array}$} & \multirow{2}{*}{$\begin{array}{l}\text { VHE } \\
115\end{array}$} & \multirow{2}{*}{$\begin{array}{l}\text { HE } \\
78\end{array}$} & \multirow{2}{*}{$\begin{array}{c}\text { LE } \\
19\end{array}$} & \multirow{2}{*}{$\begin{array}{l}\text { VLE } \\
12\end{array}$} & \multicolumn{2}{|c|}{ RESPODENTS } & \multirow{2}{*}{$\begin{array}{l}\mathbf{X} \\
3.32\end{array}$} & \multirow{2}{*}{$\begin{array}{l}\text { STD } \\
0.84\end{array}$} & \multirow{2}{*}{$\begin{array}{l}\text { DECISION } \\
\mathrm{HE}\end{array}$} \\
\hline & & & & & & Principals & 224 & & & \\
\hline & & 255 & 232 & 72 & 93 & Teachers & 652 & 3.00 & 1.04 & $\mathrm{HE}$ \\
\hline \multirow{2}{*}{22} & \multirow{2}{*}{ On-site training at supplies' factories. } & 123 & 84 & 9 & 8 & Principals & 224 & 3.44 & 0.74 & $\mathrm{HE}$ \\
\hline & & 273 & 225 & 64 & 90 & Teachers & 652 & 3.04 & 1.03 & $\mathrm{HE}$ \\
\hline 23 & On-the-job training. & 283 & 183 & 103 & 83 & Teachers & 652 & 3.02 & 1.05 & $\mathrm{HE}$ \\
\hline \multirow{2}{*}{24} & \multirow{2}{*}{ Organizing conferences, seminars and workshops. } & 101 & 86 & 12 & 25 & Principals & 224 & 3.17 & 0.96 & $\mathrm{HE}$ \\
\hline & & 236 & 269 & 63 & 84 & Teachers & 652 & 3.01 & 0.99 & $\mathrm{HE}$ \\
\hline \multirow{2}{*}{25} & \multirow{2}{*}{ Use of external resource persons. } & 85 & 96 & 25 & 18 & Principals & 224 & 3.11 & 0.89 & $\mathrm{HE}$ \\
\hline & & 285 & 214 & 67 & 86 & Teachers & 652 & 3.07 & 1.03 & $\mathrm{HE}$ \\
\hline \multirow{2}{*}{26} & \multirow{2}{*}{ Field trips and excursions. } & 93 & 85 & 27 & 19 & Principals & 224 & 3.13 & 0.93 & $\mathrm{HE}$ \\
\hline & & 243 & 281 & 87 & 41 & Teachers & 652 & 3.11 & 0.86 & $\mathrm{HE}$ \\
\hline 27 & $\begin{array}{l}\text { Vacation training through collaboration with small and medium } \\
\text { scale enterprises }\end{array}$ & 279 & 253 & 80 & 40 & Teachers & 652 & 3.18 & 0.87 & $\mathrm{HE}$ \\
\hline \multirow{2}{*}{28} & \multirow{2}{*}{ Apprenticeship education system. } & 88 & 102 & 21 & 13 & Principals & 224 & 3.18 & 0.83 & $\mathrm{HE}$ \\
\hline & & 288 & 239 & 61 & 64 & Teachers & 652 & 3.15 & 0.95 & $\mathrm{HE}$ \\
\hline \multirow{2}{*}{29} & \multirow{2}{*}{ Short Internship training programme. } & 82 & 96 & 22 & 24 & Principals & 224 & 3.05 & 0.94 & $\mathrm{HE}$ \\
\hline & & 278 & 255 & 62 & 57 & Teachers & 652 & 3.16 & 0.92 & $\mathrm{HE}$ \\
\hline
\end{tabular}




\begin{tabular}{|c|c|c|c|c|c|c|c|c|c|c|}
\hline \multicolumn{11}{|c|}{ ITEMS } \\
\hline $\mathbf{S} / \mathbf{N}$ & $\begin{array}{l}\text { Please indicate your level of awareness of the various types } \\
\text { of school-based practices requisite for entrepreneurship } \\
\text { skills acquisition in your school }\end{array}$ & VHE & HE & LE & VLE & \multicolumn{2}{|c|}{ RESPODENTS } & $\mathbf{x}$ & STD & DECISION \\
\hline \multirow{2}{*}{30} & Establishment of entrepreneurship centres and workshops in & 91 & 83 & 28 & 22 & Principals & 224 & 3.08 & 0.96 & HE \\
\hline & schools. & 271 & 275 & 57 & 49 & Teachers & 652 & 3.18 & 0.88 & $\mathrm{HE}$ \\
\hline \multirow{2}{*}{31} & \multirow{2}{*}{ Organizing technical visits. } & 106 & 87 & 17 & 14 & Principals & 224 & 3.27 & 0.85 & $\mathrm{HE}$ \\
\hline & & 263 & 279 & 62 & 48 & Teachers & 652 & 3.16 & 0.88 & $\mathrm{HE}$ \\
\hline \multirow{2}{*}{32} & \multirow{2}{*}{ Assigning projects to students during school holidays. } & 94 & 105 & 13 & 12 & Principals & 224 & 3.25 & 0.79 & $\mathrm{HE}$ \\
\hline & & 256 & 228 & 50 & 118 & Teachers & 652 & 2.95 & 1.09 & $\mathrm{HE}$ \\
\hline \multirow{2}{*}{\multicolumn{2}{|c|}{ Overall Mean and Standard Deviation }} & & & & & Principals & 224 & 3.16 & 0.92 & HE \\
\hline & & & & & & Teachers & 652 & 3.09 & 0.97 & $\mathrm{HE}$ \\
\hline
\end{tabular}

Results from Table 3 showed that both respondents' responses (principals and teachers) from items from 21 to 32 rated above the accepted mean score of 2.50 indicating agreements with all the statements in the items. None of the items rated below the mean score. The grand mean of the principals and teachers were 3.16 and 3.09 with standard deviation of 0.92 and 0.97 , respectively, indicating high positive reactions from both parties concerning their level of awareness of the types of school-based practices requisite for entrepreneurship skills acquisition in secondary schools in Delta State, which was to a high extent.

Table 4. Percentage Scores of Principals concerning their Acceptability of School-Based Practices for Entrepreneurship Skills Acquisition in Secondary Schools in Delta State $N=224$.

\begin{tabular}{|c|c|c|c|c|c|c|c|c|c|}
\hline \multirow{3}{*}{$\mathbf{S} / \mathbf{N}$} & \multicolumn{9}{|l|}{ ITEMS } \\
\hline & \multirow{2}{*}{$\begin{array}{l}\text { Please indicate your agreement on the acceptability of school-based } \\
\text { practices necessary for students' academic learning for entrepreneurship } \\
\text { skills acquisition in your school }\end{array}$} & \multicolumn{4}{|c|}{ FREQUENCIES } & \multicolumn{4}{|c|}{ PERCENTAGES } \\
\hline & & SA & $\mathbf{A}$ & NA & SNA & SA & $\mathbf{A}$ & NA & SNA \\
\hline 33 & $\begin{array}{l}\text { I accept the use of learning through transaction with local and external agents in } \\
\text { improving students' entrepreneurship skills acquisition. }\end{array}$ & 20 & 32 & 72 & 100 & 9 & 14.3 & 32.1 & 44.6 \\
\hline 34 & $\begin{array}{l}\text { I prefer on-site training at supplies' factories as a means for improving students' } \\
\text { learning and entrepreneurship skills. }\end{array}$ & 82 & 70 & 32 & 40 & 36.6 & 31.3 & 14.3 & 17.9 \\
\hline 36 & $\begin{array}{l}\text { Conferences, seminars and workshops should be organized as part of training } \\
\text { programmes for entrepreneurship skills. }\end{array}$ & 73 & 85 & 40 & 26 & 32.6 & 38 & 17.9 & 11.6 \\
\hline 37 & $\begin{array}{l}\text { I agree that external resource persons should be engaged to inculcate } \\
\text { entrepreneurship skills on students. }\end{array}$ & 102 & 100 & 10 & 12 & 45.5 & 44.6 & 4.5 & 5.4 \\
\hline 38 & $\begin{array}{l}\text { I accept organizing field trips and excursions for students' entrepreneurship } \\
\text { skills acquisition. }\end{array}$ & 99 & 115 & 6 & 4 & 44.2 & 51.3 & 2.7 & 1.8 \\
\hline 40 & $\begin{array}{l}\text { Apprenticeship system should be incorporated in the school for entrepreneurship } \\
\text { skills acquisition. }\end{array}$ & 93 & 123 & 3 & 5 & 41.5 & 55 & 1.3 & 2.2 \\
\hline 41 & $\begin{array}{l}\text { I agree to the use of short Internship training programme in order to improve } \\
\text { students' entrepreneurship skills. }\end{array}$ & 104 & 106 & 4 & 10 & 46.4 & 47.3 & 1.8 & 4.5 \\
\hline 42 & $\begin{array}{l}\text { I accept the establishment of entrepreneurship centres, laboratories and } \\
\text { workshops in schools for students' entrepreneurship skills acquisition in } \\
\text { different subject areas. }\end{array}$ & 90 & 128 & 2 & 4 & 40.2 & 57.1 & 0.9 & 1.8 \\
\hline 43 & $\begin{array}{l}\text { I agree that technical visits should sometimes be organized for students' } \\
\text { entrepreneurship skills acquisition. }\end{array}$ & 113 & 97 & 7 & 7 & 50.5 & 43.3 & 3.1 & 3.1 \\
\hline 44 & $\begin{array}{l}\text { I agree to assigning projects to students during school holidays for their } \\
\text { entrepreneurship skills acquisition. }\end{array}$ & 105 & 108 & 6 & 5 & 46.7 & 48.2 & 2.7 & 2.2 \\
\hline \multicolumn{2}{|r|}{ 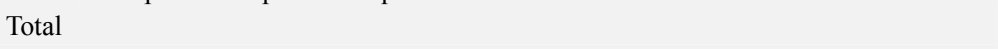 } & \multirow{2}{*}{\multicolumn{4}{|c|}{224}} & $37 \%$ & $43 \%$ & $10 \%$ & $10 \%$ \\
\hline \multicolumn{2}{|c|}{ Overall Total } & & & & & \multicolumn{2}{|c|}{$\begin{array}{l}80 \% \\
\text { Acceptability }\end{array}$} & \multicolumn{2}{|c|}{$\begin{array}{l}20 \% \\
\text { Non-Acceptability }\end{array}$} \\
\hline
\end{tabular}

Results from Table 4 indicated that $37 \%$ of the principals strongly accepted the school-based practices for entrepreneurship skills acquisition in the secondary schools in Delta State. $43 \%$ of their responses showed that the items were acceptable to them, while $10 \%$ of the principals' responses showed that the items were not acceptable to them. Also, $10 \%$ of the principals showed that the items were strongly not acceptable to them. Put together, an overall $80 \%$ of some of principals' responses revealed acceptability on most of the items, indicating agreements with the statements. While an overall $20 \%$ of their responses showed nonacceptability of most of the items and this indicating disagreements with the statements. 
Table 5. Percentage Scores of Entrepreneurship-Taught Subject Teachers concerning their Acceptability of School-Based Practices for Entrepreneurship Skills Acquisition in Secondary Schools in Delta State $N=652$.

\begin{tabular}{|c|c|c|c|c|c|c|c|c|c|}
\hline \multirow{3}{*}{$\mathbf{S} / \mathbf{N}$} & \multicolumn{9}{|l|}{ ITEMS } \\
\hline & \multirow{2}{*}{$\begin{array}{l}\text { Please indicate your agreement on the acceptability of school-based } \\
\text { practices necessary for students' academic learning for entrepreneurship } \\
\text { skills acquisition in your school }\end{array}$} & \multicolumn{4}{|c|}{ FREQUENCIES } & \multicolumn{4}{|c|}{ PERCENTAGES } \\
\hline & & SA & $\mathbf{A}$ & NA & SNA & SA & $\mathbf{A}$ & NA & SNA \\
\hline 45 & $\begin{array}{l}\text { I accept the use of learning through transaction with local and external agents in } \\
\text { improving students' entrepreneurship skills acquisition. }\end{array}$ & 58 & 100 & 284 & 210 & 8.9 & 15.3 & 43.6 & 32.2 \\
\hline 46 & $\begin{array}{l}\text { I prefer on-site training at supplies' factories as a means for improving students' } \\
\text { learning and entrepreneurship skills. }\end{array}$ & 102 & 155 & 120 & 275 & 15.6 & 23.8 & 18.4 & 42.2 \\
\hline 47 & $\begin{array}{l}\text { I accept on-the-job training should form part of the school-based programme for } \\
\text { entrepreneurship skills acquisition. }\end{array}$ & 145 & 210 & 147 & 150 & 22.2 & 32.2 & 22.6 & 23 \\
\hline 48 & $\begin{array}{l}\text { Conferences, seminars and workshops should be organized as part of training } \\
\text { programmes for entrepreneurship skills. }\end{array}$ & 310 & 245 & 57 & 40 & 47.6 & 37.6 & 8.7 & 6.1 \\
\hline 49 & $\begin{array}{l}\text { I agree that external resource persons should be engaged to inculcate } \\
\text { entrepreneurship skills on students. }\end{array}$ & 298 & 308 & 26 & 20 & 45.7 & 47.2 & 4 & 3.1 \\
\hline 50 & $\begin{array}{l}\text { I accept organizing field trips and excursions for students' entrepreneurship } \\
\text { skills acquisition. }\end{array}$ & 272 & 305 & 37 & 38 & 41.7 & 46.8 & 5.7 & 5.8 \\
\hline 51 & $\begin{array}{l}\text { I prefer school vacation training through collaboration with small and medium } \\
\text { scale enterprises as part of students' learning for entrepreneurship skills } \\
\text { acquisition. }\end{array}$ & 355 & 234 & 30 & 33 & 54.5 & 35.9 & 4.6 & 5.1 \\
\hline 52 & $\begin{array}{l}\text { Apprenticeship system should be incorporated in the school for entrepreneurship } \\
\text { skills acquisition. }\end{array}$ & 268 & 275 & 79 & 30 & 41.1 & 42.2 & 12.1 & 4.6 \\
\hline 53 & $\begin{array}{l}\text { I agree to the use of short Internship training programme in order to improve } \\
\text { students' entrepreneurship skills. }\end{array}$ & 330 & 211 & 55 & 56 & 50.6 & 32.4 & 8.4 & 8.6 \\
\hline 54 & $\begin{array}{l}\text { I accept the establishment of entrepreneurship centres, laboratories and } \\
\text { workshops in schools for students' entrepreneurship skills acquisition in } \\
\text { different subject areas. }\end{array}$ & 256 & 322 & 38 & 36 & 39.3 & 49.4 & 5.8 & 5.5 \\
\hline 55 & $\begin{array}{l}\text { I agree that technical visits should sometimes be organized for students' } \\
\text { entrepreneurship skills acquisition. }\end{array}$ & 312 & 304 & 20 & 16 & 47.9 & 46.6 & 3.1 & 2.5 \\
\hline 56 & $\begin{array}{l}\text { I agree to assigning projects to students during school holidays for their } \\
\text { entrepreneurship skills acquisition. }\end{array}$ & 407 & 218 & 17 & 10 & 62.4 & 33.4 & 2.6 & 1.5 \\
\hline Total & & 652 & & & & $40 \%$ & $37 \%$ & $11 \%$ & $12 \%$ \\
\hline \multicolumn{2}{|c|}{ Overall Total } & & & & & \multicolumn{2}{|c|}{ Acceptability } & \multicolumn{2}{|c|}{ Non-Acceptability } \\
\hline
\end{tabular}

Results from Table 5 indicated that $40 \%$ of the entrepreneurship-taught subject teachers strongly accepted the school-based practices for entrepreneurship skills acquisition in the secondary schools in Delta State. 37\% of their responses showed that the items were acceptable to them, while $11 \%$ of the teachers' responses showed that the items were not acceptable to them. Also, $12 \%$ of the entrepreneurship subject teachers showed that the items were strongly not acceptable to them. Put together, an overall $77 \%$ of some of entrepreneurship-taught subject teachers' responses revealed acceptability on most of the items, indicating agreements with the statements. While an overall $23 \%$ of their responses showed non-acceptability of most of the items and this indicating disagreements with the statements.

\section{Discussion}

The finding in Table 1 revealed the existing situation which calls for the introduction of school-based practices for entrepreneurship skills acquisition in secondary schools in Delta State. This situation included that teaching methodology in the school which is basically theoretical needs to be improved with practical knowledge and skills. Students are not currently been exposed to out-door classroom practices in different subject areas for skill acquisition. The entrepreneurial culture are not inculcated into the students to enable them develop positive attitude to work. There is existence of poor students' preparation for future career in the world of work. Unemployment problem in the country, which calls for entrepreneurship skills acquisition, is also another situation. There is need for improved partnership with external business enterprises which is not found in the secondary school system and the difficulty in meeting up with instructional objectives of certain subjects that needs practical exercises. As well, students' are poorly exposure and knowledgeable about different practices that will improve students' learning. Failure to create a functional education system and supportive classroom environment that will meet up with the present day needs and demands of the Nigerian society and economy. Failure in providing students with training that will enable them to become creative and innovative. There is need to actualize the educational and curriculum objectives through school-based practices. The secondary school system fails to effectively expose students to real life experiences that will make them become self-reliant. This finding concurs with [5] which reported that concerns about matters such as; the availability of skilled labour, lack of competition, favourable government policy and economic climate, need to achieve the educational policy objectives on entrepreneurship proficiency, supportive legislation and easy access to 
markets, individuals ability to grow their business contributed towards the need to strengthen school-based practices for entrepreneurship skills acquisition.

The finding in Table 2 revealed the benefits of schoolbased practices for students' entrepreneurship skills acquisition in secondary schools in Delta State. This included that school-based practices prepares students' mindset to undertake the risk and challenges of venturing into new business opportunities. They improve students' competences which will make them become creative and innovative in various business areas. They provide practical training for students' to acquire competences that will make them selfreliant and productive individuals in the world of work. Equips students with business, vocational, technical and communication skills that will enable them grow and improve their business in future. They create employment opportunities for students in different careers. Enables students become successful entrepreneurs in their various vocations and businesses. They further improve the quality of learning in different subject areas in the school which helps to draw students' attention and focus in a career.

The finding agrees with [1] which indicated that entrepreneurship education raises awareness of students about business skills, knowledge, promoting creativity, innovation and self-employment. This includes the acquisition of skills (through school-based practices) in areas that will be useful to business students and make them selfreliant, independent and productive citizens of the society. In this regards, the preparation of secondary school students for entrepreneurship skills acquisition is largely dependent on the acquisition of basic knowledge about employment opportunities and possession of marketable skills which can be acquired through school-based practices. The findings of [1] further indicated that skills acquired through entrepreneurship would enable students to analyze and identify the current and foreseeable skill needs to business, in terms of management, administrative and technical skills and relative importance of these. Identify the entrepreneur's own personal goals, objectives and analyze and evaluate his/her own skills and resources in relation to these. Produce a realistic personal development plan for the potential entrepreneur. Monitor on-going performance on follow-up of the entrepreneur once the business has started and progress made towards developing the new skills that had been previously identified as necessary for the success of the business. For instance, a student who undergoes school-based skill apprenticeship training would possess the following qualities; interest, ability, aptitude, patience, personality characteristics and other human physical qualities that would enable them to succeed [1]. In agreement with the above statements, Barret cited in [1] also listed as benefits, the following as skills acquired through entrepreneurship training as: technical skills: which has to do with writing, oral communication, monitoring environment, technical business management, technology, interpersonal, listening, ability to recognize, network building, management style, coaching and being a team player. Business management skills: which include planning and goal setting, decision making, human relationship, marketing, finance, accounting, management, control, negotiation, venture, launch and managing growth. Personal entrepreneurial skills which include inner control discipline, risk taking, innovative, change oriented, persistent visionary leader and the ability to manage change. However, this involves the personal needs of the entrepreneur as well as helping employees in new skills development which will be of immense benefit to the business. In Cooney's work, wealth creation and creating different employment opportunities for measuring growth were the most important benefits of schoolbased entrepreneurship programme. Nwangwu [3] therefore articulates the benefits of school-based entrepreneurship education and practices on students' skills acquisition to include: providing graduates with adequate training that will enable them to be creative and innovative in identifying noble business opportunities; providing functional education for youths so as to enable them to be self-employed and selfreliant; and likewise providing graduates with adequate training in the acquisition of skills that will enable them to meet the manpower needs of the society.

The finding in Table 3 revealed that the level of awareness of both principals and entrepreneurship-taught subject teachers on the types of school-based practices requisite for entrepreneurship skills acquisition in secondary schools in Delta State was to a high extent. This result indicated that the principals and teachers were highly aware and knowledgeable about the various types of school-based practices requisite for entrepreneurship skills acquisition. This included that both the principals and entrepreneurshiptaught subject teachers were aware of such school-based practices as; learning through transaction with local and external agents, on-site training at supplies' factories, on-thejob training, organizing conferences, seminars and workshops, use of external resource persons, field trips and excursions, vacation training through collaboration with small and medium scale enterprises, apprenticeship education system, short internship training programme, establishment of entrepreneurship centres and workshops in schools, organizing technical visits and assigning projects to students during school holidays. This findings agrees with [9] which pointed out some school-based training programmes for facilitating and inculcating entrepreneurship skill acquisition, in which schools are exposed to, as establishment of workshops with specialized tools and equipment training, apprenticeship, on-site training at supplies' factories, on-thejob training, learning through transaction with local and external agents, and learning-by-doing in the area of production and maintenance. The finding in Table 4 indicated that a large percentage of the secondary school principal accepted the incorporation of school-based practices as part of academic programme necessary for entrepreneurship skills acquisition. This included that they accepted use of all the above listed types of school-based practices for students' entrepreneurship skills acquisition in various subject areas where entrepreneurship is taught, except for learning through transaction with local and external agents, and on-the-job 
training which the principals showed their disagreements on.

The finding in Table 5 indicated that a large percentage of entrepreneurship-taught subject teachers accepted the incorporation of school-based practices as part of academic programme necessary for entrepreneurship skills acquisition. This included that they accepted use of all the various school-based practices for students' entrepreneurship skills acquisition in various subject areas where entrepreneurship is taught, except for one of them learning through transaction with local and external agents. The findings of Table 4 and 5 clearly stated percentages of both the principals and entrepreneurship-taught subject teachers' acceptability on the various school-based practices which are requisite for entrepreneurship skills acquisition in secondary schools in Delta State. These two findings revealed both parties choices on each of the school-based practices. However, the findings agree with research report of Barr and Miller cited in [11] which made it clear that best practices could be marred if the physical environment that promotes learning is not put in place and sustained. However, school-based practices can succeed in the secondary schools in Delta State only if there is rapport, well established rapport with and within groups, example: principals and teachers. Supporting this finding, the studies of [13] and [14] maintained that the crux of the matter is that a teaching procedure, whatever it may be, works well not just because of what it is in itself but because it meets the requirements of the learning situation to which it is applied. This means that effective school-based practices, incorporating an array of teaching strategies that support intellectual engagement, connectedness to the wider world, supportive classroom environments, and recognition of difference, should be implemented across all key learning and subject areas in business education and other studies.

\section{Conclusion}

This study examined the school-based practices essential for entrepreneurship skills acquisition in secondary schools in Delta State. The findings revealed the existing situation in the secondary education which necessitates these practices in the school system. The benefits, types of school-based practices and including principals and teachers acceptability of these school-based practices for entrepreneurship skills acquisition were also discovered. Failure for educational practitioners and stakeholders which include curriculum developers, secondary education board, State Ministry of Education, parents, researchers in education, policy makers in the State House of Assembly, principals and teachers to show priority interest and explore this teaching methodology has great consequences on the students' learning. This means that students' will always be exposed to theoretical knowledge while other aspects neglected and when they graduate from the school system, they will still not be competent to face challenges in the environment. Thus, few recommendations have been proffered.

\section{Recommendations}

1. State Government should provide adequate funds that will promote school-based practices in the secondary education system.

2. Adequate resources should be utilized as a way of enhancing school-based practices in the secondary education system.

3. Non Governmental agencies and other private institutions should support school-based practices by rendering to secondary schools some financial assistance, support resource provision and assisting schools to collaborate with enterprises that will boost school-based practices in the secondary education system.

4. Principals should encourage teachers to use schoolbased practices to support their teachings.

5. Education stakeholders including the Secondary Education Management Board in the school should support school-based practices.

\section{References}

[1] N. S. Ezeani, The teacher and skills acquisition at business education: From the perspective of accounting skills. Arabian Journal of Business and Management Review (OMAN Chapter), 2 (4), 2012a, pp25-36.

[2] R. A. Atakpa, Entrepreneurship education: A Sine Qua-non in business education in Nigeria. Business Education Journal, 1(11), 2011, pp1-6.

[3] I. G. O. Nwangwu, Entrepreneurship in education. Concepts and constraint. African Journal of Education and Development Studies, 4 (1), 2007, pp 196-207.

[4] National Research Center for Career and Technical Education, Work-based learning opportunities for high school students, 2013. Retrieved from http://www.nrccte.org/.

[5] T. M. Cooney, Entrepreneurship skills for growth-orientated businesses, 2012. Retrieved from https://www.oecd.org/.

[6] O. E. Olawolu, \& L. E. S. Kaegon, Entrepreneurship education as tool for youth empowerment through higher education for global workplace in Rivers, 2012. A paper presented at the Seventh Regional Conference on Higher Education for a Globalized world organized by the Higher Education Research and Policy Network (HERPNET): holding at the University of Ibadan, Ibadan Nigeria between the 17th to 21 st September, 2012.

[7] S. Johnson, N. Snowden, S. Mukhuty, B. Fletcher, \& T. Williams, Entrepreneurship skills: Literature and policy review, 2015. Retrieved from https://www.gov.uk/government/.

[8] N. S. Ezeani, Application of entrepreneurship education: Panacea for effective secondary schools management in Nigeria. Singaporean Journal of Business Economics, and Management Studies, 1 (5), 2012b, pp 27-45.

[9] S. J. Ukit, Entrepreneurship in automobile technology education: Challenges and prospects. In V. V. Apagu, J. C. Obunadike \& T. U. Ekpo (Eds). Entrepreneurship education in Nigeria: Challenges and prospects. Onitsha: Global Academic Group Online Academic Resources, 2015. 
[10] A. Chike-Okoli, Issues in school administration. Minna: ASODOC Publishing House, 2007.

[11] I. C. Odogwu, Best practices in pedagogical applications in technical education at tertiary level, 2013. Retrieved from http://www.unn.edu.ng/publications/publications/files/12312_ Best.
[12] L. Chapuis, Pedagogy: Embedding learning technologies. Australian Capital Territory Education and Training, 2003. Retrieved from http://www.principals.in/uploads/pdf/Pedagogy.

[13] B. A. Ogwo, \& R. N. Oranu, Methodology in formal and nonformal technical/vocational education. Enugu: Ijejas Printers \& Publishers Company, 2006. 